UDC 620.179.1

\title{
SURFACE DEFORMATION RELIEF FEATURES UNDER MULTIAXIAL FATIGUE
}

\section{Mykhailo Karuskevych $^{1}$; Tetiana Maslak ${ }^{1}$ ' Lukasz Pejkowski²}

\author{
${ }^{1}$ National Aviation University, Kyiv, Ukraine \\ ${ }^{2}$ Uniwersytet Technologiczno-Przyrodniczy, Bydgoszcz, Poland
}

\begin{abstract}
Summary. The paper presents experimental results directed on the development of new empirical criterion for multiaxial fatigue. The proposed criterion may be applied for materials responding the cyclical loading by the formation of deformation relief, i.e. system of extrusions, intrusions, persistent slip bands. The tests were carried out on aluminum alloy D16AT, the aluminum cladding layer of which is able to react cyclical loading by formation and evolving of relief pattern.
\end{abstract}

Key words: aircraft, multiaxial fatigue damage, deformation relief, extrusion/intrusion structure.

https://doi.org/10.33108/visnyk_tntu2019.04.045

Received 05.01.2020

Introduction. The standard mechanical performances of structural materials taken for the design of machines and vehicles have the results of the tests from the uniaxial loading. Basic information about the behavior of structural materials under cyclic loading is represented by the Wöhler curve, also obtained under uniaxial loading. At the same time, most of the constructions work under multiaxial loading conditions. For practical use of standard characteristics of materials in such conditions, equivalent stresses calculated in one way or another are used, i.e. tension stresses providing the same equivalent multiaxial damage. The relevance of the problem, the variety of materials and the conditions of their loading led to the development of a set of theories and methods for multiaxial damage calculation. A critical analysis presented in [1] contains a review of some modern approaches to the calculation of multiaxial loading strength.

The experimental confirmation of any fatigue life estimation method is the essential step for the theoretical model, is the possibility to improve and confirm the model. The empirical model considered in this article also needs theoretical and experimental substantiation, and the analysis of existing theories of strength shows, it does not counteract to the deformation or energy criteria used for the multiaxial fatigue analyses.

Extrusion/intrusion structure as an indicator of accumulated uniaxial fatigue. The conclusion about the possibility to estimate the accumulated fatigue damage under uniaxial loading by the saturation of deformation relief was done after the many years of single-crystals of aluminium investigation [2] and the investigation of structural aluminium alloys D16AT, 2024-T3, 7075-T6, B95 [3-4].

The following aspects were studied: surface relief nature as a result of dislocation motions and effect of crystal orientations, the surface deformation relief evolution under the cyclic loading, the fractal nature of the deformation relief and its dimensions, geometry of twodimensional and three-dimensional relief images, and other processes and characteristics. The deformation relief was studied with regular and program loadings, the relief monitoring was carried out under loading with axial loads and under bending conditions.

The conducted research has shown that the deformation relief is a reliable indicator of accumulated fatigue damage and can be used to predict the residual life of the corresponding 
structural elements. At the same time, it is possible not only to control the damage of structural elements, but also to use fatigue sensors attached to the structure. Such sensors are mounted on structural elements, the material of which does not demonstrate the surface relief.

Along with the relief studies conducted mainly by light microscopy methods and described in detail in [2-4], the new results have been obtained recently using research methods and techniques of the new generation.

The deformation relief morphology on the surface of pure aluminium of D16AT was investigated by the Atomic Force Microscope Dimension ${ }^{\mathrm{TM}} 3100$ (AFM) (Figure 1).

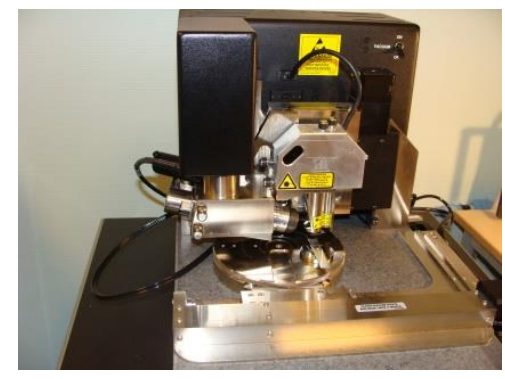

a)

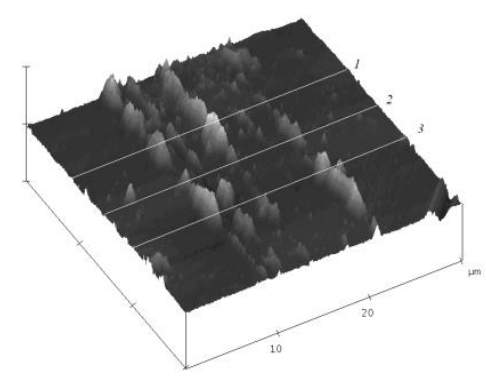

b)

Figure 1. Atomic force microscope (a) and 3D character of the deformation relief (b)

The investigation of the persistent slip bands on the surface (Figure $1 \mathrm{~b}$ ) of the specimens subjected to the 22000 cycles of loading under the bending with $\sigma_{\max }=234,5 \mathrm{MPa}$, $\mathrm{R}=0$ shows the geometry (table 1 ) of the extrusion/intrusion structure of the deformation relief.

Table 1

The geometry of the extrusion/intrusion structure of the deformation relief under uniaxial loading

\begin{tabular}{|c|c|c|}
\hline Scan line & $\begin{array}{c}\text { The range of the height of the extrusion, } \\
\mathrm{h}_{\mathrm{e}^{\prime}} \mathrm{nm}\end{array}$ & $\begin{array}{c}\text { Deep of the intrusion, } \\
\mathrm{h}_{\mathrm{i}} \mathrm{nm}^{\prime} \mathrm{nm}\end{array}$ \\
\hline 1 & $272,69-455,02$ & 67,332 \\
\hline 2 & $201,57-276,48$ & 96,79 \\
\hline 3 & $379,69-411,46$ & 25,46 \\
\hline
\end{tabular}

The optical monitoring of the deformation relief evolution proves the origin of the stage of relief saturation, which depends on the regimes of loading. After the relief, saturation (seen by the light microscopy) the geometry of extrusion/intrusion structure continue to change. For example, for the current tests the height of the extrusion reaches to the $1273 \mathrm{~nm}$ after 180000 cycles, increment is in $180 \%$. So, it is mean that the geometry of relief structure continue the increase and even on the saturation stage. The atomic force microscopy can be as an effective instrument for the quantitative analyses of the surface deformation relief.

Extrusion/intrusion structure as an indicator of accumulated fatigue under combined bending and torsion loading. The successful use of deformation relief indicators to control accumulated fatigue damage under uniaxial loading stimulates the continuation of research to substantiate the possibility to control multiaxial fatigue damage using previously proposed damage parameters. The first stage included the testing of compact samples of the D16AT alloy on a specially designed fatigue test machine that allows combine bending and torsion loading.

The deformation relief evolution under uniaxial bending loading at $\sigma_{\max }=100 \mathrm{MPa}, \mathrm{R}=0$ is presented on the figure 2 . The main deformation relief parameter is the damage parameter $\mathrm{D}$, equal 
to the ratio of black signs area (results of micro plastic deformation seen by the light microscope) to the total investigated area taken by the light microscope with magnification $250^{\mathrm{x}}$.

The relief sensitivity to the modes of loading was proved by the compare of relief images under the combined action of bending and torsion with images obtained under bending (figure 3 ). The maximum stress at the bending was $\sigma_{\max }=100 \mathrm{MPa}$. The combined action was resulted by the same value, so the equivalent stress according to Mises criteria was $\sigma_{\mathrm{eq}}=100 \mathrm{MPa}$ as well.

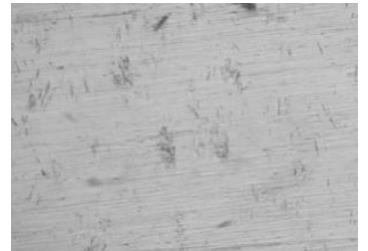

a)

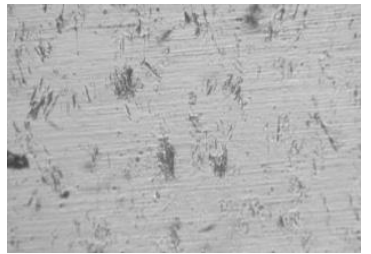

b)

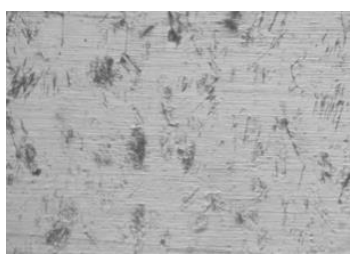

c)

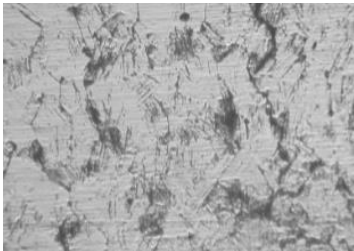

d)

Figure 2. The deformation relief evolution under uniaxial loading: a) $\mathrm{N}=60000$ cycles (5.6\% of life span); b) $\mathrm{N}=160000$ cycles $(14.9 \%)$; c) $\mathrm{N}=500000$ cycles $(46.5 \%)$; d) $\mathrm{N}=1000000$ cycles $(93 \%)$

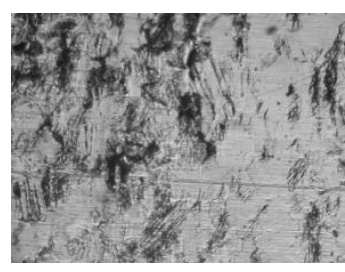

a)

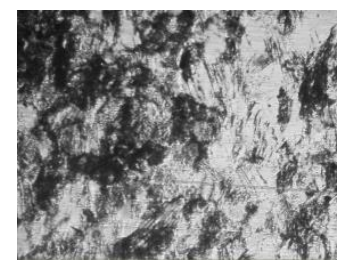

b)

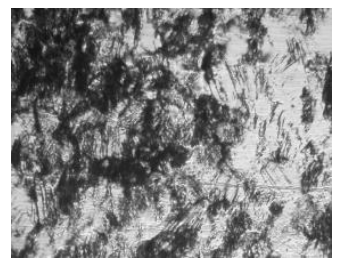

c)

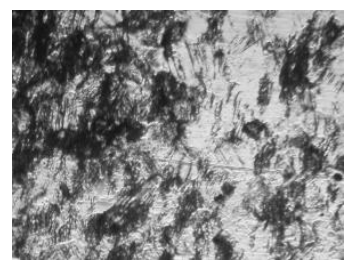

d)

Figure 3. The deformation relief evolution under the combined bending and torsion loading at $\sigma_{\text {eq }}=100 \mathrm{MPa}, \mathrm{R}=0$ : a) $\mathrm{N}=20000$ cycles $(9.8 \%$ of life span); b) $\mathrm{N}=60000$ cycles $(29.3 \%)$;

c) $\mathrm{N}=130000$ cycles $(63.5 \%)$; h) $\mathrm{N}=190000$ cycles $(92.8 \%)$

The evolution of the damage parameter under bending loading and combined bending and torsion loading is presented at the figure 4 .

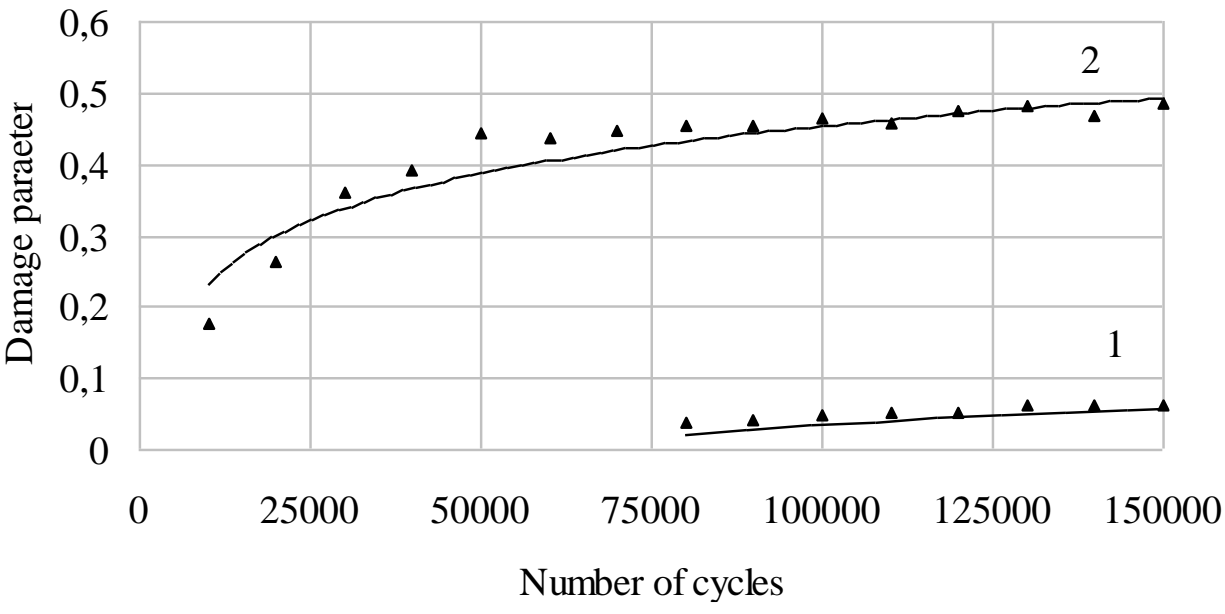

Figure 4. The damage parameter evolution under bending loading (1) with $\sigma_{\max }=100 \mathrm{MPa}, \mathrm{R}=0$ and under the combined bending and torsion loading (2) $\sigma_{\text {eq }}=100 \mathrm{MPa}, \mathrm{R}=0$

The failure of the specimen tested under the biaxial loading (bending and torsion) was at 204800 cycles of loading, and failure of the specimen under uniaxial loading (bending) was at 
1075000 cycles. Thus, the multiaxial loading has more strong effect on the damage accumulation process; this was proved by the decrease of the number of cycles to failure and more intensive development of deformation relief.

As it seen from the presented results the deformation relief is sensitive to the mode of loading and the saturation stage is also reached at different stage of fatigue life.

Extrusion/intrusion structure as an indicator of accumulated fatigue under combined in-phase and out-of- phase tension/torsion. The presented fatigue tests results under the combined action of bending and torsion stimulated the expansion of the spectrum of tests, samples, methods of processing the results and their interpretation. The tests under combined in-phase (IP) and out-of- phase (OP) loading were carried out with standard specimens of D16AT alloy (Figure 5) on the Instron 8874 Axial-Torsional Servo Hydraulic Fatigue Testing System. Inspection of the surface patterns was conducted by light metallographic microscope Delta Optical IM-100. Among the set of rather expected results presenting different combinations of loading modes the diagrams of figure 6 indicates the sensitivity of surface pattern to the mode of loading, whether it is under out-of-phase or under in-phase loading. This phenomenon requires detailed study.

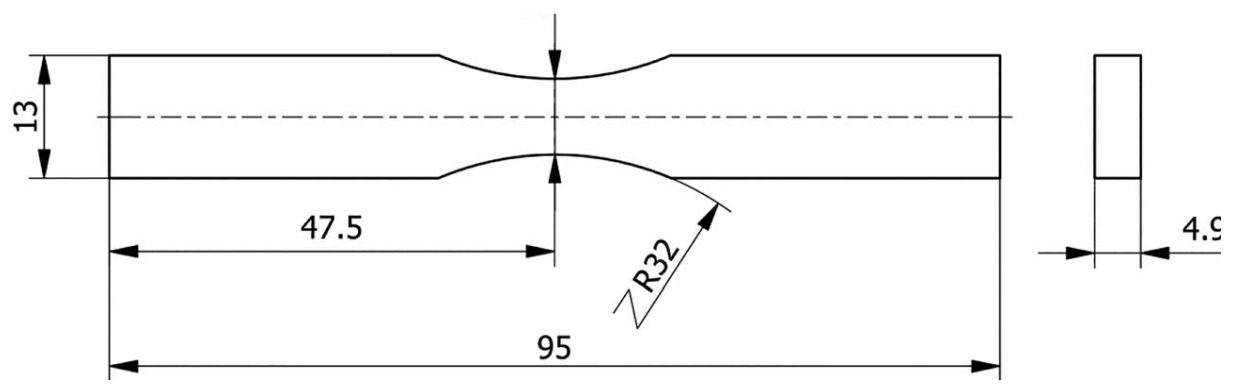

Figure 5. Specimen for fatigue tests under combined IP and OP loading

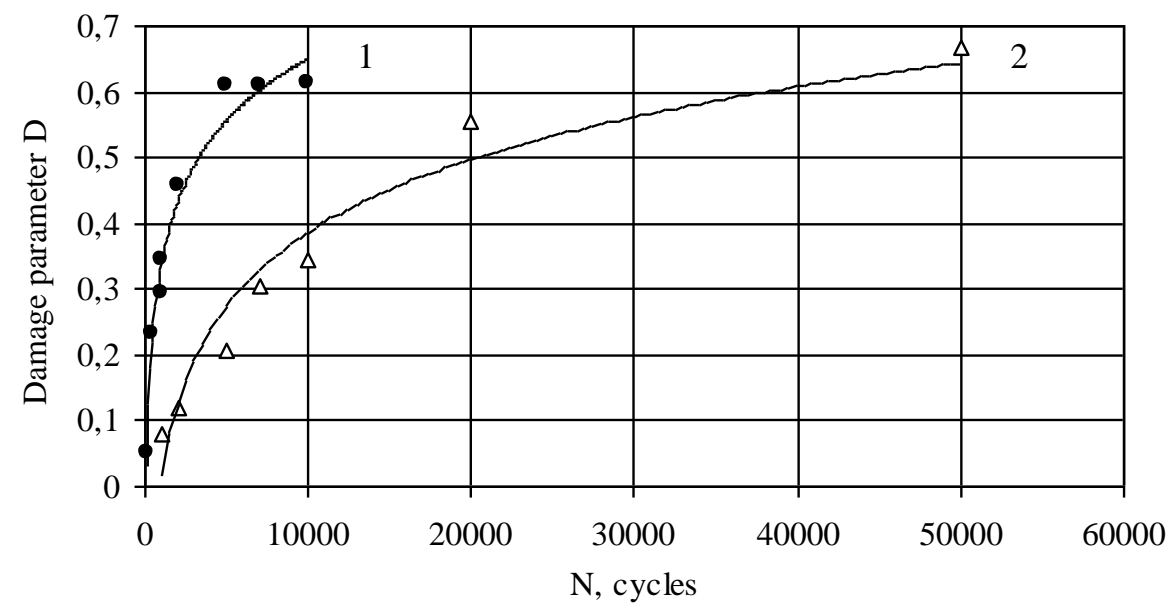

Figure 6. Damage parameter evolution under combined loading: 1 - out-of-phase; 2 - in-phase loading

The most difficult case of loading in terms of residual life estimation and interpretation of results is out-of- phase multiaxial loading.

Practical application of the results. It was proved early that the deformation relief analysis provides rather accurate prediction of remaining life of components made of alcald aluminium alloys. Example of the aircraft part suitable for this kind of inspection is a skin of the fuselage. Taking into account the fact of fuselage multiaxial mode of loading and the 
possibility to monitor and analyze features of multiple slip under the multiaxial fatigue the accuracy of the prediction can be improved. Another way to use discussed phenomena is to develop new generation of fatigue sensors intended for multiaxial fatigue assessment. The fatigue sensor can have view of cruciform specimen for fatigue testing being attached by that or another method.

Conclusion. Deformation relief or system of intrusions, extrusions and persistent slip bands is a respond of metal dislocation structure on mechanical loading. It has been observed both under the uniaxial and multiaxial cyclical loading. The number of actuated slip systems influenced by the stress-strain state: for more components of loading more slip systems are actuated. The actuating of additional slip systems leads to the changes in the relief morphology. Thus, the sensitivity of metal structure to the mode of loading and correspondent features of surface pattern allows application of surface relief for the fatigue assessment not only for uniaxial loading, but for the multiaxial fatigue as well.

\section{References}

1. Kenmeugne B., Soh Fotsing B. D., Anago G. F., Fogue M., Robert J.-L., Kenne J.-P. On the evolution and comparison of multiaxial fatigue criteria. International Journal of Engineering and Technology. 2012. Vol. 4. № 1. P. 37-46.

2. Karuskevich M. V., Radchenko A. I., Zasimchuk E. E. Single-crystal as an indicator of fatigue damage. Fatigue Fract. Engng. Mater. Struct. 1992. Vol. 15. № 12. P. 1281-1283. https://doi.org/10.1111/j.14602695.1992.tb01263.x

3. Karuskevich M., Karuskevich O., Maslak T., Schepak S. Extrusion/intrusion structures as quantitative indicators of accumulated fatigue damage. International Journal of Fatigue. ISSN: 0142-1123. 2012. Vol. 39. P. 116-121. https://doi.org/10.1016/j.ijfatigue.2011.02.007

4. Karuskevych M. V., Zhuravel' I. M., Maslak T. P. Application of Fractal Geometry to the Problems of Prediction of the Residual Service Life of Aircraft Structures. Materials Science. ISSN: 1068-820X 2012. Vol. 47. Issue. 5. P. 621-626. https://doi.org/10.1007/s11003-012-9436-7

5. Karuskevich M. V., Vogt J. B., Serre I. P., Maslak T. P. Surface relief sensor for Structural Health Monitoring. Fatigue behaviour: from specimen to structure (JIP 2013): 13-the intern. spring meeting, 2223 May 2013. Paris: 2013, P. 18.

\section{Список використаної літератури}

1. Kenmeugne B., Soh Fotsing B. D., Anago G. F., Fogue M., Robert J.-L., Kenne J.-P. On the evolution and comparison of multiaxial fatigue criteria. International Journal of Engineering and Technology. 2012. Vol. 4. № 1. P. 37-46.

2. Karuskevich M. V., Radchenko A. I., Zasimchuk E. E. Single-crystal as an indicator of fatigue damage. Fatigue Fract. Engng. Mater. Struct. 1992. Vol. 15. № 12. P. 1281-1283. https://doi.org/10.1111/j.14602695.1992.tb01263.x

3. Karuskevich M., Karuskevich O., Maslak T., Schepak S. Extrusion/intrusion structures as quantitative indicators of accumulated fatigue damage. International Journal of Fatigue. ISSN: 0142-1123. 2012. Vol. 39. P. 116-121. https://doi.org/10.1016/j.ijfatigue.2011.02.007

4. Karuskevych M. V., Zhuravel' I. M., Maslak T. P. Application of Fractal Geometry to the Problems of Prediction of the Residual Service Life of Aircraft Structures. Materials Science. ISSN: 1068-820X 2012. Vol. 47. Issue. 5. P. 621-626. https://doi.org/10.1007/s11003-012-9436-7

5. Karuskevich M. V., Vogt J. B., Serre I. P., Maslak T. P. Surface relief sensor for Structural Health Monitoring. Fatigue behaviour: from specimen to structure (JIP 2013): 13-the intern. spring meeting, 2223 May 2013. Paris: 2013, P. 18. 


\title{
УДК 620.179.1
}

\section{ОСОБЛИВОСТІ ДЕФОРМАЦІЙНОГО РЕЛЬЕФУ В УМОВАХ БАГАТООСЬОВОГО ВТОМНОГО ПОШКОДЖЕННЯ}

\author{
Михайло Карускевич ${ }^{1}$; Тетяна Маслак'; Лукаш Пейковський ${ }^{2}$ \\ ${ }^{1}$ Наиіональний авіаиійний університет, Київ, Украӥна \\ ${ }^{2}$ Університет науки і технології, Бидгощ, Польща
}

\begin{abstract}
Резюме. Наведено результати експериментального дослідження спрямовані на створення нового емпіричного критерію оцінювання багатоосьового втомного пошкодження. Запропонований критерій можна застосувати для матеріалів, на поверхні яких під дією ииклічного навантаження формується деформачійний рельєф-екструзї, інтрузї, смуги ковзання. Випробування проводилися для зразків з алюмінієвого сплаву Д16АТ, алюмінієвий плакуючий шар якого реагує на ииклічні навантаження у вигляді формування та еволюиії кластерів рельєфу. Чутливість деформаційного рельєфу до видів навантажування була підтверджена порівнянням зображення рельєфу в умовах двоосьового навантаження, згин разом з крученням з рельєфом, котрий формувався на поверхні зразків, щзо випробовувалися лише при цииклічному згині. Доказано, щзо багатоосьове навантаження має сильніший ефект на прочес накопичення пошкодження. Також представлено результати дослідження еволючії деформаційного рельєфу поверхні зразків, щзо випробовувалися при комбінованому синхронному та несинхронному навантажуванні, показано чутливість поверхневої структури $i$ до такої моди навантажування. Аналіз деформаційного рельєфу забезпечує достатньо точне прогнозування залишкової довговічності компонентів, які виготовлені з плакованих алюмінієвих сплавів. Прикладом застосування даного підходу є аналіз втомного пошкодження конструктивних елементів літака, щуо працюють 8 умовах багатоосьового навантаження. Іншою можливістю використання явища, щуо розглядається в статті, є розроблення нового покоління сенсорів втоми, призначених для очінювання багатоосьової втоми. Сенсор втоми може мати хрестоподібний вигляд для втомних випробувань, закріплений тим чи іншим чином.
\end{abstract}

Ключові слова: літак, багатоосьове втомне пошкодження, деформаційний рельєф, екструзійно/інтрузійна структура. 